\title{
Embryo early cleavage, number of blastomeres and morphology at day three as factors to predict blastocyst development
}

\author{
Clivagem precoce do embrião, número de blastocistos e morfologia \\ embrionária no dia 3 como fatores preditivos para o desenvolvimento \\ até blastocisto
}

 \\ ${ }^{1}$ Institutional affiliation:Unit of Reproductive Medicine Department of Obstetrics and Gynecology \\ Clinica Las Condes Accredited Redlara center \\ 2 Program of Ethics and Public Policies in Human Reproduction, University Diego Portales
}

\begin{abstract}
Objective: the objective of this study is to evaluate markers of embryo quality, applied on day three of in vitro culture, in their capacity to predict whether embryos will reach blastocyst stage.

Methods: a retrospective analysis of embryology database coming from 2772 zygotes obtained in 564 oocyte retrievals was performed; embryos were observed from day one to five: 23 to 26 hours after insemination all zygotes were evaluated to assess early cleavage, the number of blastomeres and embryo morphology were registered on day three and blastocyst formation was evaluated on day five; early first cleavage, number of blastomeres and embryo morphology at day three were correlated with embryo development until day five.

Results: blastocyst formation rate was $36 \%$ in embryos with early cleavage and $19 \%$ in embryos without early cleavage, $43.6 \%$ in embryos with $\geq 7$ blastomeres and $12.8 \%$ in embryos with $\leq 6$ blastomeres at day three, the probability of a good quality embryo (grade 1 and $2 a$ ) at day three to reach the blastocyst stage was $48 \%$, which was significantly higher than the chances of lower quality embryos.

Conclusion: factors reported in this study - early cleavage, number of blastomeres and embryo morphology - are useful to decide a prolonged in vitro culture until day five. Key words: blastocyst, expanded blastocyst, early cleavage, blastomere number, embryo morphology.
\end{abstract}

\section{RESUMEN}

Objetivo: el objetivo del presente trabajo es evaluar los marcadores de calidad embrionaria, observados el tercer día de cultivo, para predecir el desarrollo del embrión hasta blastocisto.

Métodos: se realizó un análisis retrospectivo de la base de datos del Laboratorio de Embriología, que proviene de 2772 cigotos obtenidos de 564 aspiraciones foliculares; los embriones fueron evaluados desde el día uno al quinto de desarrollo, registrando lo siguiente, 23 a 26 horas después de la inseminación, todos los cigotos fueron evaluados para determinar el clivaje temprano; el día 3 de desarrollo se evaluó el número de blastómeros y morfología embrionaria; el día quinto se evaluó la formación de un blastocisto, se correlacionó el clivaje temprano, el número de blastomeros y la morfología embrionariaa con el desarrollo embrionario hasta el día quinto.

Resultados: la tasa de blastulación fue $36 \%$ en embrio- nes con clivaje temprano y $19 \%$ en los embriones sin clivaje temprano, de $43,6 \%$ en embriones con $\geq 7$ blastómeros y $12,8 \%$ en embriones con $\leq 6$ blastómeros en día 3, la probabilidad de los embriones de buena calidad (grado 1 y 2a) en día 3 de desarrollo de alcanzar el estadío de blastocisto fue de $48 \%$, que fue significativamente mejor que la probabilidad de los embriones de peor morfología.

Conclusión: los factores reportados en este estudio clivaje temprano, número de blastomeros y morfología embrionaria - son útiles para decidir el cultivo prolongado in vitro hasta día quinto de desarrollo embrionario. Palabras claves: blastocisto, blastocisto expandido, clivaje temprano, número de blastomeros, morfología embrionaria. Objetivo: Avaliar os marcadores da qualidade embrionária, observados no dia 3 de cultivo in vitro, em sua capacidade de prever o desenvolvimento até o estágio de blastocisto. Métodos: análise retrospectiva do banco de dados de embriologia, proveniente de 2772 zigotos obtidos em 564 recuperações de ovócitos; embriões foram observados desde o dia 1 até o cinco: 23 a 26 horas após a inseminação todos os zigotos foram avaliadas para verificar a clivagem precoce, o número de blastômeros e morfologia embrionária foram registrados no dia três e a formação de blastocistos foi avaliada em cinco dias; a primeira clivagem, o número de blastômeros e morfologia do embrião no terceiro dia foram correlacionados com o desenvolvimento do embrião até cinco dias. Resultados: a taxa de formação de blastocistos foi de $36 \%$ em embriões com clivagem inicial e 19\% em embriões sem clivagem precoce, $43,6 \%$ em embriões com $\geq 7$ blastômeros e de $12,8 \%$ em embriões com $\leq 6$ blastômeros no dia três, a probabilidade de um embrião de boa qualidade (grau 1 e 2 a) no dia três para atingir a fase de blastocisto foi de $48 \%$, o que foi significativamente mais elevado do que as probabilidades de embriões de menor qualidade. Conclusão: Os fatores relatados neste estudo - a clivagem precoce, número de blastômeros e morfologia do embrião sãoúteis para decidircultivo prolongado in vitro até cinco dias. Palavras-chave: blastocisto, blastocisto expandido, clivagem precoce, número de blastômeros, a morfologia do embrião.

\section{INTRODUCTION}

Nowadays, the aim of assisted reproductive technologies (ART) is to obtain high pregnancy rates and reduce multiple pregnancies. For this purposes, many embryo selection criteria for cleavage stage embryos have been 
developed in order to select the best embryos and reduce the number of them to be transferred at day three (Geraedts \& Gianaroli, 2012). However, the probability of live birth is significantly higher after blastocyst stage embryo transfer as compared to cleavage stage embryo transfer, when equal number of embryos are transferred (Papanikolaou et al., 2008; Glujovsky et al., 2012) Moreover, in selected patients, the extended embryo culture until day five allows single blastocyst transfer, with a significant drop in the rate of multiple births (Practice Committee of Society for Assisted Reproductive and Practice Committee of American Society for Reproductive, 2012). Therefore, when it is possible, blastocysts instead of cleavage stage embryos should be transferred (Glujovsky et al., 2012; Practice Committee of Society for Assisted Reproductive and and Practice Committee of American Society for Reproductive, 2012). The goal is to identify which patients are suitable for extended culture and embryo development until day five. The age of women has been a key factor to determine the length of in vitro culture and, in general, patients less than 40 years are more likely to have embryos exposed to prolonged culture (Janny \& Menezo, 1996; Pantos et al., 1999). However, the most important factor to be considered is the number of good quality embryos at day three, being four the minimum suggested (Papanikolaou et al., 2005).

The main objective of this study is to evaluate the relationship between embryo characteristics, as markers of embryo quality at day three of in vitro culture, and its chances to achieve the blastocyst stage on day five. Embryo early first cleavage, number of blastomeres and morphology on day three were assessed, as factors to predict blastocyst development.

\section{METHODS}

This is a retrospective analysis of embryology database collected from January 2006 to December 2011 at the Unit of Reproductive Medicine of the Department of Obstetrics and Gynecology at Clinica Las Condes, Chile. A total of 473 patients undergoing 546 cycles were included in the study. Their general characteristics are shown in table 1. All patients signed institutional review board approved consent forms before initiating treatment and any patient specific identifiers were removed from database prior the analysis.

Table 1 shows general characteristics of 473 patients and 546 cycles included in the study. Women received the same stimulation protocol, consisting of leuprolide acetate from the preceding luteal phase, followed by daily injections of 150-300 IU of follicular stimulating hormone (FSH), either pure or combined with luteinizing hormone $(\mathrm{LH})$, starting on day two of the cycle. Once follicles reached $18-20 \mathrm{~mm}$ and oestradiol/follicle $>17$

Table 1. General characteristics of 473 patients and 546 cycles included in the study.

\begin{tabular}{lc}
\hline Age & $\mathbf{3 4 . 9 \pm 3 . 6}$ \\
\hline Total dose of FSH (IU) & $1884 \pm 665$ \\
\hline Aspirated follicles & $16.5 \pm 7.8$ \\
\hline Oocytes retrieved & $12.3 \pm 5.3$ \\
\hline Inseminated oocytes & $6.9 \pm 2.8$ \\
\hline Fertilization rate & $76.2 \%$ \\
\hline Transferred embryos & $2.4 \pm 0.6$ \\
\hline Pregnancy rate & $46.5 \%$ \\
\hline Implantation rate & $27.5 \%$ \\
\hline Miscarriage rate & $8.7 \%$ \\
\hline Multiple pregnancy rate & $37.4 \%$ \\
\hline
\end{tabular}

$\mathrm{mm}$ was found to be at least $900 \mathrm{pmol} / \mathrm{L}, 10.000 \mathrm{IU}$ of human chorionic gonadotropin (hCG) was administered. Follicular aspiration for oocyte retrieval was performed 36 hours later.

Intracytoplasmic sperm injection (ICSI) was performed in all cases. The oocytes were stripped of their cumulus cells after incubation in Hyaluronidase solution ( 80 $\mathrm{UI} / \mathrm{mL}$, Life Global ${ }^{\mathrm{TM}}$, USA) for 60 seconds. Spermatozoa were selected by swim up procedure and ICSI was performed with micropipettes (Humagen ${ }^{\mathrm{TM}}$, USA) under an Olympus inverted microscope and a Narishige micromanipulation system. Injected oocytes were incubated in Global Fertilization Media (Life Global ${ }^{\mathrm{TM}}$, USA) in a $6 \%$ $\mathrm{CO} 2$ incubator (Forma Scientific ${ }^{\mathrm{TM}}$, USA). Eighteen hours after sperm injection oocytes were inspected for fertilization and those fertilized were transferred to Fresh Global Media (Life Global ${ }^{\mathrm{TM}}$, USA). Pronucleous characteristics were not considered for this study. A total of 2772 zygotes from 564 oocyte retrievals were followed from day one to five. Twenty four to 26 hours after ICSI, all zygotes were evaluated microscopically to assess whether the two pronucleous had disappeared or early cleavage had taken place. Number of cells and embryo morphology was assessed at day three using criteria reported by Veeck (Veeck, 1999), which considers cell number, uniformity and size of blastomeres, and the extent of fragmentation. Each embryo was designated based on its cell number and grade of uniformity and fragmentation, bein grade 1 symmetric blastomeres without fragmentation, grade 2 a symmetric blastomeres and less than $20 \%$ of fragmentation, grade $2 b$ symmetric blastomeres and 20 to $50 \%$ of fragmentation, grade 3 uneven size of blastomeres, without fragmentation and grade 4 uneven blastomeres with fragmentation. Blastocyst formation an quality were evaluated on day five, using criteria reported by Veeck and Zaniovic (Veeck \& Zaninovic, 2003), where a good quality blastocyst is characterized by an early cavitation, resulting in the formation of an eccentric and expanded cavity lined by a distinct inner-cell mass and trophectoderm layer with a thin Zona Pellucida.

Embryo early first cleavage, number of blastomeres and morphology on day three were correlated with in vitro development of the embryo to day five and blastocyst quality. The same parameters were retrospectively assessed in blastocysts having $100 \%$ implantation (implantation of all blastocysts transferred). Statistic analysis was performed using Chi Square test ( $X^{2}$ test), fixing the level of significance at 0.05 .

\section{RESULTS}

Overall, embryo development to blastocyst of the entire population of zygotes (2772) was $30.1 \%$. The percentage of embryos arrested was: $1.4 \%$ at day one, $7.9 \%$ at day two, $18.5 \%$ at day three and $42.2 \%$ at day 4 . Blastocyst formation was $36.8 \%$ in 1687 embryos with early cleavage and dropped to $19.6 \%$ in 1085 embryos without early cleavage $(p<0.0001 ; C I 13.8$ to 20.4$)$. Among 620 blastocysts coming from embryos with early cleavage $16.6 \%$ were good quality compared with $9.8 \%$ within 213 blastocysts without early cleavage $(p=0.0235$; $95 \%$ CI 1.79 to 11.71 ). Regarding the number of blastomeres at day three, blastocyst formation rate was $43.6 \%$ in 1529 embryos with $\geq 7$ blastomeres and $12.8 \%$ in 1223 embryos with $\leq 6$ blastomeres at day three $(p<0.0001$; $95 \%$ CI 27.7 to 33.9). Among 668 blastocysts coming from embryos with $\geq 7$ blastomeres $16.9 \%$ were good quality versus $7.64 \%$ within 157 blastocysts with $\leq 6$ blastomeres ( $p=0.0054 ; 95 \%$ CI 4.23 to 14.29$)$. Table 2 shows analysis of blastocyst formation rates of embryos with $<6$ to $\geq 10$ blastomeres at day three and table 3 shows development of zygotes to blastocysts and its quality depending on embryo morphology, assessed at day three.

Eighty-five blastocysts from 41 patients had $100 \%$ implantation. Table 4 shows the developmental profile of these implanted blastocysts. 
Table 2. Blastocyst formation rates depending on number of embryo blastomeres at day three.

\begin{tabular}{|c|c|c|c|c|c|c|}
\hline $\begin{array}{l}\text { Number of } \\
\text { blastomeres }\end{array}$ & $<6$ & 6 & 7 & 8 & 9 & $\geq 10$ \\
\hline $\begin{array}{l}\text { Number of } \\
\text { embryos }\end{array}$ & 668 & 555 & 379 & 1043 & 51 & 55 \\
\hline $\begin{array}{l}\text { Blastocyst } \\
\text { formation } \\
\text { rate }\end{array}$ & $\begin{array}{c}0.66 \% \\
\text { (a) }\end{array}$ & $\begin{array}{c}20.4 \\
\% \\
\text { (b) }\end{array}$ & $\begin{array}{c}37.9 \% \\
\text { (c) }\end{array}$ & $\begin{array}{l}45.6 \% \\
\text { (d) }\end{array}$ & $\begin{array}{l}50.9 \\
\% \\
(\mathrm{e})\end{array}$ & $\begin{array}{l}40.0 \\
\% \\
\text { (f) }\end{array}$ \\
\hline
\end{tabular}

a versus $b$ p $<0.00001 ; 95 \%$ CI 16.3 to 23.1

b versus c $\mathrm{p}<0.00001 ; 95 \%$ CI 11.6 to 23.4

c versus $d p=0.0122 ; 95 \%$ CI 1.96 to 13.4

${ }^{d}$ versus $e$ and e versus $f$ NS

$\mathrm{X}^{2}$ test

Table 3. Development of zygotes to blastocysts and blastocyst quality depending on embryo morphology assessed at day three.

\begin{tabular}{lcccl}
\hline $\begin{array}{l}\text { Embryo } \\
\text { morphology }\end{array}$ & $\begin{array}{c}\text { Grade 1 } \\
\text { and 2a }\end{array}$ & $\begin{array}{c}\text { Grade } \\
\mathbf{2 b}\end{array}$ & Grade 3 & Grade 4 \\
\hline $\begin{array}{l}\text { Number of } \\
\text { embryos }\end{array}$ & 1349 & 712 & 117 & 594 \\
\hline $\begin{array}{l}\text { Blastocyst } \\
\text { formation } \\
\text { rate }\end{array}$ & $\begin{array}{c}48.0 \% \\
\text { (a) }\end{array}$ & $\begin{array}{c}20.5 \% \\
\text { (b) }\end{array}$ & $\begin{array}{c}17.1 \% \\
(\mathrm{c})\end{array}$ & $\begin{array}{l}3.2 \% \\
(\mathrm{~d})\end{array}$ \\
\hline $\begin{array}{l}\text { Number of } \\
\text { blastocysts }\end{array}$ & 648 & 146 & 20 & 19 \\
\hline $\begin{array}{l}\text { Proportion of } \\
\text { good quality } \\
\text { blastocysts }\end{array}$ & $\begin{array}{c}16.2 \% \\
(\mathrm{e})\end{array}$ & $\begin{array}{c}13 \% \\
(\mathrm{f})\end{array}$ & $10 \%(\mathrm{~g})$ & $\begin{array}{l}10.5 \% \\
(\mathrm{~h})\end{array}$ \\
\hline
\end{tabular}

a versus $b$ p $<0.0001 ; 95 \%$ CI 23.5 to 31.5

b versus $c$ NS

versus $d p<0.00001 ; 95 \%$ CI 6.9 to 20.9

e versus $f, g$ and $h$ NS

$\mathrm{X}^{2}$ test

Table 4. Early cleavage, number of blastomeres and embryo morphology at day three of 85 blastocysts having $100 \%$ implantation.

\begin{tabular}{l|ccc}
\hline & $\begin{array}{c}\text { Early } \\
\text { cleavage }\end{array}$ & $\begin{array}{c}\text { Embryos } \\
\text { with } \geq 7 \\
\text { blastomeres }\end{array}$ & $\begin{array}{c}\text { Grade 1 and } \\
\text { 2a embryos }\end{array}$ \\
\hline $\begin{array}{l}\text { Number of } \\
\text { embryos }\end{array}$ & 73 & 84 & 78 \\
\hline Proportion & $85,9 \%^{a}$ & $98,8 \%^{b}$ & $91,8 \%^{c}$ \\
\hline
\end{tabular}

a versus $b$ NS

a versus C NS

\section{DISCUSSION}

Many parameters have been used to predict the outcome of cleaving embryos, such as the speed of cleavage (Luna et al., 2008), number of blastomeres (Shapiro et al., 2000; Langley et al., 2001; Luna et al., 2008) and embryo morphology at day 3 (Rijnders \& Jansen 1998; Stone et al., 2005; Nomura et al., 2007), all of which, provide relevant elements to evaluate the capacity of cleaving embryos to reach blastocyst. This study combines all parameters, allowing a comparison between them, and also provides novel information about the characteristics of developing embryos when blastocysts have $100 \%$ implantation.

Shapiro and Langley (Shapiro et al., 2000; Langley et al., 2001) reported that rates of blastocyst formation and expansion increased as the number of blastomeres at 72 hours increased and Luna (Luna et al., 2008) reported that a significantly higher number of embryos with 7-9 and $\geq 10$ cells at day three reached the blastocyst stage, compared with embryos with $\leq 6$ cell at day three. Results from this study confirm previous findings and suggest that in order to reach blastocyst stage, the threshold of blastomeres that cleaving embryos should have at day three of development is 7 . Indeed, with $\geq$ 7 cells at day three an embryo has $43.6 \%$ of chances to achieve the blastocyst stage. As was also demonstrated by Langley (Langley et al., 2001), blastocysts development did not increase further when embryos had more than 8 cells on day three. However, there was not significant difference in embryo development to blastocyst when day three embryos had 8-10 or more cells (Table 2 ), which reaffirms that fast cleaving embryos are as good as embryos with 8 cells to accomplish the blastocyst stage. This result is similar to that reported by Luna (Luna et al., 2008), and reaffirm that fast cleavage at day three is not a poor prognostic factor for the embryo. On the other hand, as was also suggested by Shapiro (Shapiro et al., 2000), the probability of reaching a good quality blastocyst from an embryo with $\geq 7$ cells on day three is more than two fold the chances an embryo with $\leq 6$ blastomeres on day three has to reach day five being an expanded blastocyst.

This study also uses another criterion to evaluate embryo cleavage velocity, which is the assessment of early cleavage. Using this parameter a highly significant number of embryos having an early cleavage reached the blastocyst stage compared with those embryos without early cleavage. This has also been reported in many other species, as mouse, monkey, buffalo and bovine (MCLaren \& Bowman 1973; Bavister et al., 1983; Totey et al., 1996; Lonergan et al., 1999) and is a valuable element to predict which embryos can reach the blastocyst stage. Furthermore, blastocysts quality was better when early cleavage was present, with a higher proportion of good quality blastocysts in the group of early cleavage embryos. This finding confirms the value of early cleavage as a strong indicator, not only for blastocyst formation but also for its quality (Lundin et al., 2001; Neuber et al., 2003; Van Montfoort et al., 2004; Giorgetti et al., 2007), which appears to have a very close relation with implantation rates and the success of blastocyst transfer (Balaban et al., 2000).

Embryo morphology at day three has been reported to be a good predictor for the chances of an embryo to achieve the blastocyst stage (Rijnders \& Jansen 1998; Stone et al., 2005; Nomura et al., 2007). The analysis of data in this study demonstrates that the probability of grade 1 and 2 a embryos to get to blastocyst stage is $48 \%$ (Table 3 ), which is significantly higher than the chances of embryos with grade 3 or 4 (3.2\%). Coincidently, Graham (Graham et al., 2000) reported that only $48 \%$ embryos that would have been chosen for embryo transfer and/or cryopreservation on day 3 were eventually used in such a manner at the blastocyst stage. Previous reports showed that dysmorphic embryos on day three have higher rates of aneuploidy, polyploidy and mosaicism (Munne et al., 1995) and reduces the chances of an embryo to develop until day five, althou$\mathrm{gh}$, some types of fragmentation are transient and do not diminish the likelihood of blastocyst formation (Stone et al., 2005). Nevertheless, blastocysts more commonly have a normal karyotype than cleavage-stage embryos do (Jansen et al., 2008) and this has to be considered relevant when preimplantation genetic diagnosis is not available, because an extended in vitro culture until day five could be a good alternative to select the best embryos to be transferred.

When blastocyst quality was assessed no differences were observed between blastocysts coming from grade 1 and $2 a$ and lower quality embryos at day three. This finding suggests a greater predictive value of early cleavage and number of blastomeres over classic embryo morphology to predict blastocysts quality and its implantation potential. On the other hand, when day three embryo characteristics were retrospectively assessed in the group of $100 \%$ implantation blastocysts a very high proportion of embryos having early cleavage, $\geq 7$ cells and good morphology (grade 1 and 2a) was observed (Table 4), which reinforces the value of these factors to 
select the best embryos if transfer has to be performed at cleavage stage and not at day five because not enough good embryos are available on day three to continue in vitro culture until day five. Actually, the number of good quality embryos at day three is still the most critical factor to be considered to optimize results of ART and minimize the risk to cancel the cycle due to lack of blastocysts available (Dessolle et al., 2010), being four the minimum suggested (Papanikolaou et al., 2005).

Recently developed commercial devices associating stable culture conditions and time lapse observation of embryo development provide new insights into early embryo development in ART. Results obtained with this technology give valuable information about the development of the embryo and, probably, will change embryo selection criteria according to kinetic parameters and observation of abnormal cleavage events (Freour et al., 2012). However, validation of the method, quality control and accessibility are needed to establish this as a routine technique for centers performing ART.

\section{CONCLUSION}

Predictive factors reported in this study - early cleavage, number of blastomeres and embryo morphology - should be considered to decide when embryos at day three could be exposed to an extended in vitro culture until day five, in order to obtain blastocysts for embryo transfer.

\section{Corresponding author}

Prof. Dr. Antonio MacKenna

Unit of Reproductive Medicine, Department of Obstetrics and Gynecology, Clinica Las Condes, Lo Fontecilla 441, Santiago, Chile, Postal Code 7591046.

Telephone: 560222104000

Mail: amackenn@clc.cl

\section{REFERENCES}

Balaban B, Urman B, Sertac A, Alatas C, Aksoy S, Mercan R. Blastocyst quality affects the success of blastocyst-stage embryo transfer. Fertil Steril. 2000; 74:282-287.

Bavister BD, Boatman DE, Leibfried L, Loose M, Vernon MW. Fertilization and cleavage of rhesus monkey oocytes in vitro. Biol Reprod. 1983; 28:983-999.

Dessolle L, Freour T, Barriere P, Darai E, Ravel C, Jean M, Coutant C. A cycle-based model to predict blastocyst transfer cancellation. Hum Reprod. 2010; 25:598-604.

Freour T, Lammers J, Splingart C, Jean M, Barriere P. Time lapse (Embryoscope) as a routine technique in the IVF laboratory: a useful tool for better embryo selection?. Gynecol Obstet Fertil. 2012; 40:476-480.

Geraedts JP \& Gianaroli L. Embryo selection and IVF. Hum Reprod. 2012; 27:2876-2877.

Giorgetti C, Hans E, Terriou P, Salzmann J, Barry B, ChabertOrsini V, Chinchole JM, Franquebalme E, Sitri MC, Thibault MC, Roulier R. Early cleavage: an additional predictor of high implantation rate following elective single embryo transfer. Reprod Biomed Online. 2007; 14:85-91.

Glujovsky D, Blake D, Farquhar C, Bardach A. Cleavage stage versus blastocyst stage embryo transfer in assisted reproductive technology. Cochrane Database Syst Rev. 2012; 7: CD002118.

Graham J, Han T, Porter R, Levy M, Stillman R, Tucker MJ. Day 3 morphology is a poor predictor of blastocyst quality in extended culture. Fertil Steril. 2000; 74:495-497.

Janny L \& Menezo YJ. Maternal age effect on early human embryonic development and blastocyst formation. Mol Reprod Dev. 1996; 45: 31-37.

Jansen RP, Bowman MC, de Boer KA, Leigh DA, Lieberman $\mathrm{DB}, \mathrm{McArthur} \mathrm{S}$ J. What next for preimplantation genetic screening (PGS)? Experience with blastocyst biopsy and testing for aneuploidy. Hum Reprod. 2008; 23:1476-1478.

Langley MT, Marek DM, Gardner DK, Doody KM, Doody KJ. Extended embryo culture in human assisted reproduction treatments. Hum Reprod. 2001; 16:902-908.
Lonergan P, Khatir H, Piumi F, Rieger D, Humbolt P, Boland MP. Effect of time interval from insemination to first cleavage on the developmental characteristics, sex ratio and pregnancy rate after transfer of bovine embryos. J Reprod Fertil. 1999; 117:159-167.

Luna M, Copperman AB, Duke M, Ezcurra D, Sandler B, Barritt J. Human blastocyst morphological quality is significantly improved in embryos classified as fast on day 3 ( $>$ or $=10$ cells), bringing into question current embryological dogma. Fertil Steril. 2008; 89: 358-363.

Lundin K, Bergh C, Hardarson T. Early embryo cleavage is a strong indicator of embryo quality in human IVF. Hum Reprod. 2001; 16:2652-2657.

McLaren A \& Bowman P. Genetic effects on the timing of early development in the mouse. J Embryol Exp Morphol. 1973; 30:491-498.

Munne S, Alikani M, Tomkin G, Grifo J, Cohen J. Embryo morphology, developmental rates, and maternal age are correlated with chromosome abnormalities. Fertil Steril. 1995; 64:382-391.

Neuber E, Rinaudo P, Trimarchi JR, Sakkas D. Sequential assessment of individually cultured human embryos as an indicator of subsequent good quality blastocyst development. Hum Reprod. 2003; 18:1307-1312.

Nomura $M$, Iwase A, Furui $K$, Kitagawa $T$, Matsui $Y$, Yoshikawa M, Kikkawa F. Preferable correlation to blastocyst development and pregnancy rates with a new embryo grading system specific for day 3 embryos. J Assist Reprod Genet. 2007; 24:23-28.

Pantos K, Athanasiou V, Stefanidis K, Stavrou D, Vaxevanoglou $T$, Chronopoulou $M$. Influence of advanced age on the blastocyst development rate and pregnancy rate in assisted reproductive technology. Fertil Steril. 1999; 71:1144-1146.

Papanikolaou EG, D'Haeseleer E, Verheyen G, Van de Velde $H$, Camus M, Van Steirteghem A, Devroey P, Tournaye H. Live birth rate is significantly higher after blastocyst transfer than after cleavage-stage embryo transfer when at least four embryos are available on day 3 of embryo culture. A randomized prospective study. Hum Reprod. 2005; 20:3198-3203.

Papanikolaou EG, Kolibianakis EM, Tournaye $H$, Venetis CA, Fatemi H, Tarlatzis B, Devroey P. Live birth rates after transfer of equal number of blastocysts or cleavage-stage embryos in IVF. A systematic review and meta-analysis. Hum Reprod. 2008; 23:91-99.

Practice Committee of Society for Assisted Reproductive, T. and M. and Practice Committee of American Society for Reproductive. Elective single-embryo transfer. Fertil Steril. 2012; 97:835-842.

Rijnders PM \& Jansen CA. The predictive value of day 3 embryo morphology regarding blastocyst formation, pregnancy and implantation rate after day 5 transfer following in-vitro fertilization or intracytoplasmic sperm injection. Hum Reprod. 1998; 13:2869-2873.

Shapiro BS, Harris DC, Richter KS. Predictive value of 72-hour blastomere cell number on blastocyst development and success of subsequent transfer based on the degree of blastocyst development. Fertil Steril. 2000; 73:582-586.

Stone BA, Greene J, Vargyas JM, Ringler GE, Marrs RP. Embryo fragmentation as a determinant of blastocyst development in vitro and pregnancy outcomes following embryo transfer. Am J Obstet Gynecol. 2005; 192:2014-2019.

Totey SM, Daliri M, Appa Rao KB, Pawshe CH, Taneja M, Chillar RS. Differential cleavage and developmental rates and their correlation with cell numbers and sex ratios in buffalo embryos generated in vitro. Theriogenology. 1996; 45:521-533.

Van Montfoort AP, Dumoulin JC, Kester AD, Evers JL. Early cleavage is a valuable addition to existing embryo selection parameters: a study using single embryo transfers. Hum Reprod. 2004; 19:2103-2108.

Veeck LL. An atlas of human gametes and conceptuses : an illustrated reference for assisted reproductive technology. New York: London, Parthenon; 1999.

Veeck LL \& Zaninovic N. An atlas of human blastocysts. Boca Raton: London, Parthenon; 2003. 